\title{
Model Kekuasaan Politik Ibnu Khaldun (Sebuah Pelajaran Berharga bagi Bangsa Indonesia)
}

\author{
Mansur \\ Universitas Ahmad Dahlan Yogyakarta
}

Ibnu Khaldun has been adorable for both Moslem and Western scholars because of its political thought. He has been considered as the world property, whose thought should be conserved and reproduced. This article discusses the concept of political power in accordance with Ibnu Khaldun thought. The discussion will be focused on political thought of him in relation to the reality of national leadership of Indonesia, which is now entering the political reform stages.

Keywords: Ibnu Khaldun, political thought, national leadership, reform, Indonesia.

emikiran, termasuk sang tokoh, kerapkali melakukan dialog dengan realitas. Tetapi dialog dalam konteks ini bukan dalam perspektif sosiologi pengetahuan, melainkan dalam konteks fenomena. Artinya, popularitas seorang pemikir sekaligus pemikirannya, kerapkali mengikuti perkembangan zaman. Suatu ketika seorang pemikir bisa menaiki menara gading, suatu ketika dia bisa tenggelam di hanyut air sungai.

Demikian juga, pemikir yang hendak penulis angkat kali ini. Ibnu Khaldun bukanlah nama baru dalam diskursus keilmuan Islam dan sosial. Walaupun namamya sempat tenggelam dan mungkin dianggap telah ketinggalan zaman, dalam waktu tertentu dia juga akan ditampilkan sesuai tuntutan realitas, termasuk sekarang ini dalam perbincangan tentang kepemimpinan nasional.

Pemikiran Ibnu Khaldun layak diangkat mengingat para pemikir muslim maupun Barat sama-sama mengagumi kosenpsi politiknya dan mereka menganggap Ibnu Khaldun sebagai kekayaan dunia yang harus di lestarikan dan direproduksi.

Persoalan yang hendak diangkat dalam artikel ini adalah bagaimana konsepsi kekuasaan politik menurut Ibnu Khaldun?. Tulisan ini juga terutama berguna untuk memberikan informasi akurat dan kritis tentang pemikiran politik Ibnu Khaldun sehingga kita dapat memahami pemikiran sang pemikir fenomenal ini untuk kemudian dikaitkan dengan realitas kepemimpinan nasional Indoesiaan yang kini masih gencargencarnya memasuki tahap reformasi politik.

\section{Landasan Teoritis Filsafat Politik Ibnu Khaldun}

Untuk mengetahui lebih jauh konsepsi filsafat politik Ibnu Khaldun, ada dua hal penting yang perlu penulis singgung: Ashobiah sebagai landasan teoritik dan pengaruh Ashobiah terhadap kekuasaan politik. 
UNISIA, Vol. XXX No. 66 Desember 2007

\section{Ashobiah sebagai Landasan Teoritik}

Abd. Al-Rahman Ibnu Khaldun lahir di Tunis pada awal ramadlan $732 \mathrm{H}$, atau 27 mei 1332 dan meninggal di Kairo pada 17 maret 1406 . Nenek moyangnya berasal dari Hadramaut yang kemudian bermigrasi ke Sevilla (Spanyol) pada abad ke-8 setelah semenanjung itu dikuasai Islam. Keluarga yang dikenal pro Umayyah ini selama berabad-abad menduduki posisi tinggi dalam politik di Spanyol sampai akhirnya hijrah ke Maroko beberapa tahun sebelum Sevilla Jatuh ke tangan penguasa Kristen pada tahun 1224. Setelah itu mereka tetap menetap di Tunisia.

Karena itulah, Ibnu Khaldun sebenarnya hidup pada masa kegelapan Islam, yakni sejak jatuhnya Spanyol ke tangan penguasa Kristen. Pada masa ini memang lebih dikenal sebagai masa pembukuan dan pensyarahan dari khazanah intelektual Islam terhadap era ke emasan Islam, terutama pada masa Nabi dan Khalafa alRasyidun (Toto Suharto, 2003:1). Hal ini disebabkan, Islam masih dalam tahap perkembangan dan perjuangan.

Namun demikian, dia dipandang sebagai cendikiawan muslim yang kreatif menghidangkan khazanah intelektualisme Islam pada masa abad pertengahan. Bahkan banyak orang menyebut dia sesuai dengan sudut pandang tersebut. Sosiolog memandang Ibnu Khaldun sebagai sosiolog, demikian juga ahli hukum, antropologi, politik dan sejarah bahkan negarawan (Syafii Maarif,1996:11). Lebih dari itu, Ibnu Khaldun di kenal sebagai pemikir muslim yang menggunakan pendekatan historis dalam mengkaji wacana keilmuan Islam. Karena itu, konsep sejarahnya yang dia tawarkan berbeda sekali dengan apa yang ditawarkan pada masa sebelumnya. Hal itu sebagaimana diulas dalam buku pengantarnya, Muqaddimah. Konsepsi sejarah pra Ibnu Khaldun lebih banyak menyajikan peristiwa sejarah, sementara latar belakang yang melahirkan sejarah tersebut mereka lupakan (Ibnu Khaldun,tt). Berbeda dengan mereka, Ibnu Khaldun justru mengkaji apa yang melatarbelakangi suatu peristiwa, yang dalam konsepsi lbnu Khaldun dikenal dengan Thaba'i al-Umran (dinamika internal sosial masyarakat). Di antara yang menjadi fokus kajian Ibnu Khaldun, yang dipandang sebagai salah satu hal yang melahirkan sejarah perpolitikan masa itu di dunia Arab Islam khususnya adalah Ashobiah dan inilah yang menjadi obyek analisis penulis saat ini.

Sebagaimana layaknya para pemikir Barat yang kerapkali menjadikan manusia sebagai pusat analisisnya terhadap realitas kehidupan, demikian pula Ibnu Khaldun. Pertama-tama Ibnu Khaldun menganalisis manusia. Dengan menukil pemikiran para filsuf, Ibnu Khaldun menganggap bahwa manusia secara alamiah merupakan makhluk sosial.

Salah satu teori dasar tentang manusia yang mungkin relevan dengan analisis ini adalah teori yang dikemukakan Syari'ati. Menurut Ali Sari'ati, manusia bersifat bidimensional atau dicipta dari dua unsur yaitu unsur tanah dan Ruh Tuhan (Ali Sari'ati,1982:113). Secara fisik manusia dicipta dari tanah. Dalam bahasa manusia Ali Sari'ati,1982: 113) tanah atau lumpur adalah simbol kenistaan. Tidak ada makhluk yang lebih rendah daripada lumpur. Di samping itu, tanah adalah simbol stagnasi dan possibelitas mutlak. Dengan simbol kehinaan itu, wajar jika kemudian Iblis mengklaim bahwa dirinya lebih mulia dari Adam (Depag, 1996: Quran). Tetapi di samping itu, manusia juga mempunyai 
dimensi lain yang sangat mulia yaitu dimensi Ruh. Oleh karena Ruh merupakan tiupan Tuhan secara langsung, maka manusia juga mempunyai dimensi mulia yaitu potensi keberagamaan.

Korelasinya dengan analisis ini adalah karena Ibnu Khaldun memandang manusia sebagai makhluk sosial dan makhluk yang cenderung bermusuhan. Manusia menurut Ibnu Khaldun hidup sebagai makhluk sosial. Tipe makhluk sosial ini, terkait erat dengan hal memperoleh makanan (Ibnu Khaldun, 1987:71). Dalam arti, dalam hal mencari makanan, mereka tetap butuh pada kelompok.

Walaupun Allah telah memberikan RuhNya, pikiran dan menyediakan makanan agar dikonsumsi mereka dalam mengembangkan kehidupannya, tapi mereka juga mempunyai watak binatang, yakni suka menyerang pihak lain. Ini kemungkinan sebagai konsekuensi logis dari unsur tanah sebagaimana analisis Syari'ati bahwa unsur tanah telah menghantarkan manusia pada watak kebinatangan. Diantara watak itu adalah suka bermewah-mewahan dan memusuhi orang lain tanpa memandang secara rasional. Watak ini minimal menjadi salah satu faktor mereka melakukan penyerangan dan permusuhan terhadap pihak lain. Dua sifat yang melekat ini pada hakikatnya bertumpu pada pertumbuhan dan pertahanan eksistensi manusia.

Dalam rangka memperoleh makanan dan mempertahankan diri dari serangan musuh, mereka tentu membutuhkan kelompok atau organisasi kemasyarakatan (Zainab al-Khudiri,1987:142-143). Karena itu, terjadilan proses pengelompokan. Proses pengelompokan ini menurut lbnu Khaldun terutama didasarkan pada sebab-sebab kekerabatan dan pertemanan atau persaudaraan. Tetapi, kekerabatan menurutnya lebih kuat dalam menciptakan hubungan pengelompokan ini karena pada umumnya, pertalian darah mempunyai pengikat yang kuat bagi manusia, sehingga mereka merasakan apa yang menimpa saudaranya (Zainab al-Khudiri,1987:142143). Terlepas dari mana yang lebih kuat antara kedunya, yang jelas, dua hal ini menjadi landasan utama pengelompokan.

Dalam pengelompokan ini, mereka melakukan apa yang disebut taassub. Walaupun Taassub memunculkan banyak penafsiran, sehingga berbagai pemikir yang menganalisis istilah ini dari Ibnu Khaldun kerapkali berbeda satu sama lain, hanya saja, ada satu pengertian yang mendekati kebenaran menurut Zainab Khudairi adalah solidaritas kesukuan. Sejalan dengan pengertian ini adalah apa yang ditawarkan Al Jabiri. Menurutnya, taassub yang dimaksud dalam konsepsi lbnu Khaldun adalah dalam arti maknawi bukan dzati, yaitu suatu perasaan bahwa dirinya merupakan bagian yang tak terpisahkan dari kelompok yang menjadi afiliasinya (al Jabiri,1991:213-237).

Walaupun taassub menurut Ibnu Khaldun ada dua, sebagai akibat dari hubungan darah dan pertemanan, setidaktidaknya, taassub dipahami sebagai sebuah kekuatan dalam kelompok bahkan eksistensi individu menjadi hilang dalam kelompok. Karena itu, wajar jika Montgomery Watt (1995) mengatakan bahwa dunia Arab pada waktu itu menganut humanisme suku. Dalam humanisme seperti ini, manusia secara individual menghilang diganti oleh kepentingan suku. Demi kepentingan dan eksistensi suku, mereka rela melakukan apa saja.

Konsekuensi logis sikap taassub ini adalah munculnya kesadaran yang 
bertumpu pada suku. Dalam bahasa Mark kesadaran ini disebut dengan kesadaran kelas, tetapi dalam konteks Ibnu Khaldun ia di sebut dengan kesadaran kesukuan. Dalam konteks kesadaran suku, yang dipertahankan adalah eksistensi suku dimana dia hidup, tanpa melihat benar atau salah, dlalim atau tidak (al-Jabiri, 1994:166). Selanjutnya, menurut Ibnu Khaldun, dalam kelompok suku itu diperlukan adanya otoritas, baik dalam rangka meredam konflik internal ataupun untuk mengendalikan suku dalam menghadapi lawan dari luar.

Otoritas, yang dimaksud di sini, bergantung pada konteksnya. Bagi masyarakat Badui, otoritas yang dimaksud adalah otoritas kharismatik, sementara dalam hubungannya dengan suku-suku lain, yang dibutuhkan adalah otoritas yang sangat kuat. Perlu diingat bahwa otoritas untuk satu suku tertentu, belum tentu mempunyai otoritas bagi suku lain. Hanya saja, pada umumnya otoritas suku cukup membantu dalam mempertahankan suku dari serangan musuh, dan bahkan dalam konteks sistem kerajaan.

Dengan kata lain, dalam konteks intern kelompok, biasanya yang menjadi otoritas adalah otoritas maknawi, sehingga ketika terjadi permusuhan, mereka bergantung pada raja. Dalam otoritas seperti ini, ada semacam perasaan "hutang makna" (alJabari,1994:166) pada seorang pemimpin, sehingga kebijakan pemimpin sangat berpengaruh. Tetapi dalam konteks melawan musuh dari luar, mereka butuh pada kekuatan raja. Raja di sini berpengaruh bukan saja di dalam kerajaannya, tapi juga bagi di luar kelompoknya. Di dunia Arab permusuhan antara suku sudah menjadi biasa. Memahami kondisi demikian, maka ketika melakukan perjanjian di Madinah, Muhammad masih menghargai suku.

\section{Pengertian Ashobiah}

Dari konsep taassub atau sifat solidaritas kesukuan ini, lahirlah apa yang oleh Ibnu Khaldun disebut Ashobiah, suatu landasan filosofis Ibnu Khaldun dalam melihat fenomena kekuatan sebuah negara atau tatanan politik. Menurut Ibnu Khaldun, daya kreatif yang mendasar yang mempengaruhi peristiwa politik adalah konsep "Ashobiah".

Sebagaimana pengertian taassub cukup banyak, demikian juga dengan pengertian Ashobiah, sebagai turunan dari kata taassub. Kata ini bisa berarti: rasa kelompok, solidaritas sosial, atau solidaritas kelompok. Istilah ini juga berkaitan dengan "ashaba" yang berarti "famili" yang berarti "membuat dan memperkuat keluarga". Kata ini juga berhubungan dengan istilah "ishabah" dan "ushbah" yang kedua-duanya berarti kelompok (Arkoun,2001).

Ashobiah juga berarti saling mengasihi, rela berjuang dan mati demi yang lain (Ibnu Khaldun, 1994:Ixxvii-Ixxxix). Istilah ini mulanya didasarkan atas hubungan darah yang membuat orang bersikap kasih kepada famili dan saudara-saudaranya, perasaan ini bersifat saling melindungi apabila ditimpa musibah dan kerusakan atas diri mereka (Ibnu Khaldun, 1994:ibid).

Dengan demikian, konsep Ashobiah memiliki daya pemersatu yang sanggup mengikat sejumlah individu sehingga memperoleh kekuatan dan tumbuh menjadi kelompok-kelompok yang sehat kuat dan secara politik aktif. Dan Ashobiah juga dapat dibangun oleh seorang pemimpin yang dengan efisien dapat menghubungkan anggota-anggotanya di antara pendukungpendukungnya yang bertalian darah.

Di samping itu, Ashobiah juga mengarah kepada penaklukan. Kelompok 
yang paling efektif dalam mencapai penaklukan adalah kelompok yang mempunyai ikatan Ashobiah terkuat. Kelompok ini mengungguli kelompok lain yang mempunyai rasa kelompok yang lebih lemah dan menggiring kepada kendali kekuasaannya. Hal ini sejalan dengan apa yang dikatakan oleh Ibnu Khaldun bahwa apabila suatu "Ashobiah" menguasai yang lain, maka kedua Ashobiah itu memasuki kontak hubungan yang erat. Dan Ashobiah yang kalah memberi kekuatan tambahan kepada yang menang yang akibatnya memancangkan tujuan superioritas dan sasarannya lebih tinggi dan lebih jauh dari sebelumnya (Ibnu Khaldun,1993:285-286).

Sementara itu, Ashobiah ini mulanya tumbuh subur dalam situasi yang ditandai dengan kemiskinan, kebajikan dan dedikasi. Hal ini terutama terdapat pada kelompokkelompok pemuda yang kuat, tidak manja dan pemberani. Mereka rela mengorbankan segalanya demi kebaikan orang banyak. Mereka hidup dalam kesamaan derajat dan merdeka (Ibnu Khaldun,1993:285-286). Manakala Ashobiah berjalan, segala kebajikan individual dan kebaikan politik menyertainya. Kehadiran Ashobiah menghendaki perbuatan bijak dan baik. Sedangkan ketiadaan Ashobiah ditandai dengan timbulnya kemungkarankemungkaran dan kejahatan-kejahatan (Ibnu Khaldun,1993).

Di samping Ashobiah, Ibnu Khaldun juga memberikan peranan yang besar bagi agama terhadap terhadap jatuh bangunnya suatu negara. la memandang bahwa agama secara umum memiliki "daya pemersatu" masyarakat yang melengkapi dan memantapkan Ashobiah. Dalam hal ini pengaruh agama membuat solidaritas kelompok semakin kokoh yang memungkinkan terbangunnya sebuah kerajaan. Karena itu, untuk beberapa generasi, Ashobiah bukan saja diperkuat oleh agama tapi juga karena adanya campur tangan Ilahi dalam urusan kemanusiaan. Karena segala kehendak anggota masyarakat diatur oleh keyakinan agamanya dan tabiat kebinatangannya akan terkendalikan (Gibb,1962:173). Secara khusus, agama Islam dalam pandangan Ibnu Khaldun merupakan kebenaran, hukum dan pemberian Tuhan (Stoasser, 1994:94).

Bagi Ibnu Khaldun solidaritas yang dihasilkan oleh agama jauh lebih kuat dan langgeng daripada yang dihasilkan oleh "Ashobiah" (ikatan darah biasa). Walaupun ia mengakuai adanya kelompok tanpa agama yang mempunyai solidaritas sosial internal, namun ia tetap menganggap agama sebagai daya pemersatu yang memberkati bangsa-bangsa muda dengan kekuatan untuk membangun sebuah negara (Stoasser, 1994:71).

Namun demikian, Ibnu Khaldun memandang agama - paling tidak dalam kasus agama Islam - bukan sebagai fakta sejarah, melainkan sebagai kebenaran yang memberikan prinsip yang mendasar yaitu norma abadi yang lebih penting dari semua sejarah dan perkembangan politik. Karena ia tidak pernah menganggap pemerintahan sebagai aktivitas yang otonom yang dapat membuat moralitasnya sendiri yang dipisahkan dari agama (Stoasser, 1994:74).

Namun demikian, Ibnu Khaldun tidak berbicara lebih jauh tentang agama dalam konteks perjalanan sejarah di dunia ini. Dia lebih terfokus pada meneliti fakta-fakta empiris ketimbang lari ke Tuhan secara mentah-mentah., walaupun dia tidak berarti menafikan peran agama. Karena itulah, Ibnu Khaldun melihat bahwa jatuh bangunnya suatu negara tidaklah bersifat intrinstik, tetapi disebabkan oleh faktor-faktor fisik, 
geografis, biologis, psikologis dan faktor sosial menentukan karakter dan perkembangan tindakan serta kebiasaankebiasaan manusia secara kolektif. Tetapi tidak juga berarti bahwa segala keputusan manusia ditentukan oleh lingkungan obyektif itu. Nasib manusia dan masyarakat ditentukan pilihan kolektif

Singkat kata, Ashobiah juga mengarah kepada penaklukan terhadap Ashobiah yang lemah (Ibnu Khaldun,1993:285-286). Sehingga apabila muncul Ashobiah-Ashobiah yang sama-sama kuat, bisa jadi kekuatankekuatan kelompok yang mencapai prestasi semacam itu justru akan menjadi sumber pertikaian dan konflik baru. Begitu mereka mendapat tujuan tertentu para anggota kelompok itu akan menolak tuntutan lebih jauh dari penguasanya. Mereka tentu memerlukan kekuatan tambahan untuk menghilangkan kekurangan-kekurangan itu dalam memantapkan solidaritasnya, dan daya pemersatu ini adalah agama.

\section{Pengaruh Ashobiah Terhadap Kekuasaan Politik}

Berdasarkan analisis ini, dapat dipahami bahwa Ibnu Khaldun meletakkan ashobiah sebagai penggerak negara dan merupakan landasan tegaknya suatu negara atau dinasti. Bahkan ia bisa menjadi sarana peralihan dari masayarakat bersuku pada masyarakat tanpa suku (al Khudairi, 1987:158). Sebab kekuatan untuk meraih kekuasaan menurut Ibnu Khaldun terletak pada suku, tetapi kekuatan suku tergantung pada ashobiah. Kuat yang dimaksud disini dalam arti berperang untuk mempertahankan atau meraih sesuatu kekuasaan. Karena itu, kekuasaan menurutnya tidak bersifat "de jure", melinkan "de facto" (al Khudairi, 1987:152).
Ada satu kasus menarik yang kerapkali dijadikan contoh oleh para pemerhati Ibnu Khaldun, yakni kepemimpinan Quraisy. Persyaratan ke Quraisyan seorang pemimpin menurut Ibnu Khaldun dilatarbelakangi oleh kepentingan untuk meredam konflik, sementara itu, pada waktu itu posisi unggul berada di tangan suku Quraisy.

Jika kita memahami konsepsi ini, kita juga bisa mengeneralisir alasan dan kepentingan serupa dengan konteks keQuraisyan. Ini artinya keharusan adanya Ashobiah yang merupakan syarat keabsahan pemegang tampuk kekuasaan bagi umat Islam. Dengan kata lain, pemegang tampuk kekuasaan harus berasal dari suku yang mempunyai basis sosial yang dominan, sehingga ia dapat memberikan perlindungan yang efektif terhadap rakyatnya.

Berpijak pada analisis ini, menurut penulis penetapan kepemimpinan suku Quraisy pada masanya merupakan sesuatu yang sangat rasional, karena suku Quraisy merupakan suku terkuat dari sekian suku yang ada. Tetapi rasionalitas yang dimaksud disini bukan dalam arti murni dan abstrak sebagaimana layaknya filsafat spekulatif, melainkan filsafat yang berpijak pada fakta-fakta empiris. Jadi, rasionalitas yang dimaksud disini adalah rasionalitas yang realistis.

Dengan menjadikan faktor Ashobiah sebagai fondasi dasar kekuatan negara, berarti eksistensi negara bergantung bukan pada asumsi spekulatif dan ide-ide normatif Islam sebagaimana yang gencar dipamerkan kaum fundamentalis, melainkan berkait erat dengan fakta-fakta empiris. Disinilah dapat dipahami bahwa konsepsi negara Islam tidak kaku sebagaimana konsepsi kekhilafahan. Dengan analisisnya ini, Ibnu Khaldun hendak menawarkan bahwa sistem ketatanegaraan boleh saja 
Model Kekuasaan Politik Ala Ibnu Khaldun; Mansur

tidak berbentuk formalitas Islam, sebab Islam tidak mempunyai konsep yang baku dan lepas dari realitas empiris. Justru, konsepsi Islam tentang negara menurutnya harus selalu mengikuti dinamika internal masyarakat yang dalam konsepsi lbnu Khaldun di sebut Thaba'i Umran. Jika thaba'i umran masing -masing masyarakat berbeda, tentu sistem kenegaran masyarakat tersebut juga berbeda satu sama lain. Pemutlakan ke-Quraisyan sebagai persyaratan mutlak kekuasan dalam Islam, jika berpijak pada konseisi Ibnu Khaldun, adalah sebuah pengingkaran terhadap dialektika Islam dengan relitas empiris (al Khudairi, 1987:160).

\section{Penutup}

Berbeda dengan para sejarawan sebelumnya, Ibnu Khaldun menjadikan thaba'i umran sebagai landasan dasar teori kritisnya dalam menganalisa masyarakat. Ketika dia menganalisis bagaimana perkembangan masyarakat suku dan bagaimana mereka mengalami perkembangan menuju masyarakat bernegara, Ibnu Khaldun menemukan landasan dasarnya pada kekuatan Ashobiah. Karena itu, konsepsi ashobiah sangat urgen dalam mengetahui konsepsi filsafat politik Ibnu Khaldun.

\section{Daftar Pustaka}

Arkoun, Muhammad, 2001, Islam Kontemporer, Yogyakarta: Pustaka Pelajar.

Ibnu Khaldun,1958, The Muqadimah, yang diterjemahkan dari bahasa Arab oleh
Franz Rosenthal, New York: Patheon Books.

Muhammad abed al-Jabiri, 1991,Al-Turatsa wa al-hadtsah, Dirasat wa Munawasat, Beirut:Al-Markas alTsaqafi al-Arobi.

Fikrata Ibnu Khaldun: Ashobiah wa al-Daulah, Lebanon: Beirut, 1994

al-Khudiri, Zainab,1987, Filsafat Sejarah Ibnu Khaldun, Bandung: Pustaka.

Maarif, Syafii,1996, Ibnu Khaldun dalam Pandangan penulis Barat, Jakarta: Gema Insani Press.

R. Gibb, H. A.,1962, Studies in Civilization of Islam, London: Routledge \& Kegal Paul.

Stoasser, Barbara Freyer, Agama dan Perkembangan Politik Menurut Ibnu Khaldun, dalam Jurnal Ulumul Qur'an, No. 3, Vol.V, 1994.

Suharto, Toto,2003, Epistemologi Sejarah Kritis Ibnu Khaldun, Yogyakarta: Fajar Pustaka.

Syari'ati, Ali,1982, Tentang Sosiologi Islam, Yogyakarta: Ananda.

Watt, Montgomery,1995, Pengantar Studi al-Qur'an, Jakarta: PT. Raja Grafindo Persada. 